\title{
Female Users' Behavioral Intention to Purchase in Social Commerce through Social Networking Sites
}

\author{
Phyo Min Tun \\ Assumption University, Thailand \\ Corresponding email: phyomintun.sg@gmail.com \\ do) http://dx.doi.org/10.22515/shirkah.v6i2.416
}

\begin{tabular}{|c|c|}
\hline ARTICLE INFO & ABSTRACT \\
\hline $\begin{array}{l}\text { Keywords: } \\
\text { Behavioral Intention; Female } \\
\text { SNS Users; Intention to } \\
\text { Purchase; Social Commerce }\end{array}$ & $\begin{array}{l}\text { The present study aims to discover the relationship among } \\
\text { social influence, verbal influence, easiness, trust, enjoyment, } \\
\text { and intention to purchase in social commerce (S-Commerce), } \\
\text { particularly by female users of social networking sites (SNS). }\end{array}$ \\
\hline $\begin{array}{l}\text { Article history: } \\
\text { Received: } 18 \text { April } 2021 \\
\text { Revised: } 07 \text { June } 2021 \\
\text { Accepted: } 13 \text { June } 2021 \\
\text { Available online: } 13 \text { July } 2021 \\
\text { To cite in APA style: } \\
\text { Tun, P. M. (2021). Female } \\
\text { Users' Behavioral Intention to } \\
\text { Purchase in Social Commerce } \\
\text { through Social Networking } \\
\text { Sites. Shirkah: Journal of } \\
\text { Economics and Business, 6(2), } \\
\text { 137-160 }\end{array}$ & $\begin{array}{l}\text { A total of } 280 \text { responses were collected from female SNS } \\
\text { users through an online survey. The obtained data were } \\
\text { further examined for normality, construct validity, } \\
\text { reliability, and model fit, using Structural Equation } \\
\text { Modeling (SEM) to test the hypotheses. This study } \\
\text { confirmed that social influence had a significant effect on } \\
\text { verbal influence and trust; meanwhile enjoyment was } \\
\text { influenced by trust and easiness. The results also revealed } \\
\text { that trust and enjoyment had a positive effect on intention to } \\
\text { purchase products or services from social commerce by the } \\
\text { female SNS users. Moreover, verbal influence provided an } \\
\text { impact on trust and easiness; while the relationship between } \\
\text { social influence and enjoyment, easiness, and trust was not } \\
\text { significant. These results contribute to offering fruitful } \\
\text { insights for sellers and vendors of social commerce in } \\
\text { attracting and acquiring the attention of female customers; } \\
\text { as a result, it leads to achieving higher profits and flourishing } \\
\text { business activities in social commerce. }\end{array}$ \\
\hline
\end{tabular}

This work is licensed under a Creative Commons Attribution-NonCommercial 4.0 International License.

\section{Introduction}

E-commerce is a revolutionary type of purchasing products and services but it is a lack of social interaction. Therefore, the traditional e-commerce model is gradually changing to a social-oriented environment due to the rapid development and expansion of social networking sites (SNS). The use of SNS has evolved the way of interaction between businesses and their customers (Hajli \& Sims, 2015). SNS has become a remarkable tool 
to provide effective communication and collaboration between businesses and their stakeholders (Culnan, McHugh, \& Zubillaga, 2010). Sago (2010) also stated that SNS represents one of the most important platforms for e-commerce and enhances the efficacy of communication with a large number of customers simultaneously.

SNS users are able to get information easily through their online community, and share their prior experiences or recommendations in real-time with their peers. Social interaction of customers in SNS context also offers significant value for new product and service development (Lin \& Huang, 2013). Many businesses can be found on SNS and using SNS is not only selling their products and services but also advertising, branding, engaging customer services, and finding business partners or employees (Tun, 2012). As a result, the growing popularity of SNS has created many changes, both electronically and socially, emerging a new type of e-commerce, which has been transforming the way online shopping has been done, called social commerce or SCommerce (Zhou, Zhang, \& Zimmermann, 2013).

\section{Research Motivation}

The total population of Myanmar is 54 million and 22 million populaces have internet access, and all of them are using social media. Among them, 21 million internet users are using Facebook. Despite female is major with $52 \%$ of total population, only $41.7 \%$ of total Facebook users are female (Kemp, 2020). Meanwhile, the rapid growth of the number of SNS users and the continuously increasing popularity of SNS has led to many businesses focusing on S-Commerce (Leeraphong \& Papasratorn, 2018). As a result, S-Commerce has become a significant field of exploration for researchers interested in social media technologies, and their impacts on businesses and customers (Lee \& Phang, 2015) but there are no prior research studies conducted in the Myanmar context.

In Myanmar, only 2.9\% of females are conducting online purchasing while $4.5 \%$ are male (Kemp, 2020). Slyke, Comunale, and Belanger (2002) advocated that males like to purchase online more than females do, and there are different motivations among males and females for online shopping (Sangwan, Siguaw, \& Guan, 2009). Therefore, it is necessary to identify the factors influencing female SNS users to engage and purchase more in S-Commerce. The findings of this study may help businesses in S-Commerce to better understand how to conduct their own business on SNS platforms, improve transaction processes, and formulate the marketing strategy, most notably, to attract more female customers.

Moreover, research on social commerce is still at an early phase (Baethge, Klier, \& Klier, 2016; Zhang \& Benyoucef, 2016), and this research can be considered as the first-time study to investigate the factors that influence S-Commerce context in Myanmar, especially among the female SNS users. Also, this research study attempts 
to fill the research gap in the literature and investigate the factors using a framework consisting of three different aspects: technological, social, and belief to solve the following research questions. To ensure the objectives, the present study is guided by two research questions: (1) what factors are influencing intention of female customers to purchase in social commerce? and (2) which factors are significant for female customers to involve in social commerce?

\section{Literature Review}

Social commerce (S-Commerce) is an integration of e-commerce and social activities in the social media environment, notably by using Web 2.0 technologies and SNS. Thus, S-Commerce is considered as a sub-category of e-commerce that involves the role of SNS such as Facebook to support social interaction for the online buying and selling of products and services (Ngai, Tao, \& Moon, 2015). The concept of S-Commerce is based on social media which allows the users to collaborate actively in the advertising, promoting, and selling of various products and services (Stephen \& Toubia, 2010). Customers can purchase the product and share their shopping experience at the same time, on the S-Commerce platform (Huang \& Benyoucef, 2013).

Adam, Jizat, and Nor (2016) stated that S-Commerce provides advantages and benefits for not only buyers but also sellers. The sellers can implement various business models and create profits by attracting potential customers or buyers through recommendations and sharing in SNS. Another benefit of using S-Commerce is receiving reliable information on specific products and services which were given by their customers, and that reflects mostly at selecting the best prices in purchasing (Kim \& Park, 2013). Moreover, using social media platforms, conducting commercial activities, and exchanging information about products before purchasing are three major characteristics of S-Commerce (Liang \& Turban, 2011).

\section{Theoretical Background}

Bostrom and Heinen (1977) proposed a technical-social theory based on two major subsystems: the social and technical. The social subsystem emphasizes the participants of the system and the technical subsystem is more focusing on technology usage. The utilities of social media technology and the easiness of SNS for users encompass the technical aspect (Ahmad, 2019). Technology Acceptance Model (TAM) is the most frequently used theory to identify the behavior of users in several technical contexts. Easiness (EA) in this study is a similar concept of perceived ease of use from TAM, a major predictor of users' intention to adopt a technology. According to Davis (1989), the users will perceive a technology as ease of use when it is recognized as effortless and easy. Venkatesh and Bala (2008) stated that enhancing the level of easiness of a technology will lead to higher engagement with it. Hence, EA can be referred to the 
extent to which SNS users believe that purchasing through S-Commerce would be easy to use and learn how to purchase.

Shopping is one of the social activities and shopping in S-Commerce can be referred as the commercial activities incorporated with social activities (Lu, Fan, \& Zhou, 2016). Lin, Zhang and Li (2016) argued that the harmony of the technical and social subsystems will likely lead the customers to engage more with S-Commerce platforms. Ajzen (1991) stated that social influence can be considered as an activity of interaction with a group of people or peers that make changes of actions, attitude, behaviors, feelings, and opinions of a person. Moreover, Venkatesh and Davis (2000) extended the social influence (SI) processes in TAM to enhance prediction ability on the usage of new technology. Therefore, this study employs TAM integration with SI construct to identify both technical and social enablers of adopting behavior in an online context likewise previous research studies (Biucky, Abdolvand, \& Harandi, 2017; Almaimouni, Houghton, \& Sandhu, 2014; Miranda et al., 2014).

In this study, verbal influence (VI) is a similar construct of Word-of-mouth (WOM) and it is an informal communication such as oral or spoken messages among the non-business community regarding products or services through telephone, email, social media, or any other method of communication (Goyette et al., 2010). VI can be referred as the deliberately constructed messages to attract and persuade socially individuals (Newton \& Burgoon, 2006). Also, VI in social commerce context is usergenerated content in SNS including recommendations, referrals, ratings, and reviews related to products or services (Lin, Li, and Wang, 2016). Further, VI is a suitable construct to investigate the social interactions of customers in S-Commerce environments (Wang and Yu, 2015).

Ramayah and Ignatius (2005) stated that enjoyment (EJ) is one of the major factors that encourage users to shop online. People are likely to perceive enjoyment when they realize that they are connected with peers who have similar opinions and interests in SNS, and it will lead to performing commercial activities through social media (Cho \& Son, 2019). Moreover, enjoyment (EJ) was suggested as an additional belief factor in extended TAM and played a critical role in predicting behavioral intention (BI) towards adopting new technology (Davis, Bagozzi, \& Warshaw, 1992).

Mcknight, Choudhury, and Kacmar (2002) stated that trust is a belief of trustworthiness among the participants in the online context. Additionally, several previous studies (Mutz, 2005; Pavlou \& Ba, 2002) concluded that trust is an essential element in the online environment. Gefen, Karahanna, and Straub (2003) also studied the online shopping context using TAM by supplementing trust (TR) construct. Behavioral Intention (BI) to purchase a product or service is an inevitable stage to complete an online transaction (Pavlou, 2003). According to Raza et al. (2014), purchase 
intention refers to the extent of the readiness and willingness of the customers to make a deal with the seller.

\section{Research Model and Hypotheses Development}

There will be more verbal communication within the social peers with strong social interaction than the social group with faint social interaction (Bone, 1995). Social influencers are part of the social circles and mavens to deliver and talk up-to-date information about the products, services, price comparisons, and reliable vendors (Tsai, Kuo, \& Tan, 2017). The study of Tun (2020) also proved that social influence is an important origin of verbal influence. Thus, the following hypothesis is postulated:

H1: Social influence has a significant positive effect on verbal influence.

In the purchasing process, customers listen and seek suggestions and guidance from others to reduce risks and learn the ways to purchase (Flanagin et al., 2014). Customers like to obtain information through verbal communication more when they have difficulties during high-risk purchase processes (Laughlin \& MacDonald, 2010). They think that verbal communication will help them to prevent possible flaws and eliminate errors (Mehrad \& Mohammadi, 2017). Therefore, verbal influence is a type of direct social behavior that influences customers to be perceived the ease of using SCommerce.

H2: Verbal influence has a significant positive effect on easiness.

Han and Windsor (2011) confirmed that trust in S-Commerce has a significant positive effect on the willingness of customers to purchase on the site. Moreover, social influence is more significant among female users than males according to the study of Goh and Sun (2014). In S-Commerce context, it is proposed that social influence will engender reliability and credibility about the sellers from S-Commerce (Lee, Cho, \& Bae, 2017). Hence, this study formulates the following hypothesis:

H3: Social influence has a significant positive effect on trust.

Users tend to overly rely on their social peer connection and social networks for the adoption of emerging technologies (Dickinger, Arami, \& Meyer, 2008). KoenigLewis et al. (2015) explicitly stated that it is critical to realize how social influence has a significant positive effect on the enjoyment of experiences using modern technologies. The study of Park et al. (2019) also empirically proved that social influence positively affects enjoyment. Therefore, it is posited that:

H4: Social influence has a significant positive effect on enjoyment.

SNS has become a vital role for the customers to access and spread their thoughts and experiences in shopping easily (Chu \& Choi, 2011); thus, customers are increasingly depending on informal information such as verbal communication from SNS to obtain 
the information of the products, services, and sellers to reduce their anxiety and concern before online purchasing (Kumar et al., 2020). Mehrad and Mohammadi (2017) proved that the impact of verbal communication on customers' trust is greater than the effectiveness of conventional advertising or formal promotions. Therefore, the following hypothesis is tested:

H5: Verbal influence has a significant positive effect on trust.

Customers' confidence in S-Commerce can be developed effectively if they think shopping in S-Commerce is easy and has understandable purchasing procedures (Hajli et al., 2017). Also, the presence of sufficient features in S-Commerce such as ease of navigation, lack of purchasing process complexity, and easy understanding of the structure will assist e-retailers to make a trustworthy long-term relationship with their customers (Al-Adwan, 2019; Gefen, Karahanna, \& Straub, 2003). This leads to formulate the following hypothesis:

H6: Easiness has a significant positive effect on trust.

The earlier study of Sukhu, Zhang, and Bilgihan (2015) determined that easiness of using SNS enhances the positive impression of customers which leads to greater enjoyment. Previous studies also confirmed that ease of use has a positive relationship with enjoyment (Ashfaq et al., 2019; Chesney, 2006) and the easiness of using SCommerce is expected to have a positive effect on customers' perception of enjoyment in shopping in the present study. Therefore, the following hypothesis can be proposed:

H7: Easiness has a significant positive effect on enjoyment.

In an online shopping environment, trust is crucial for customers to feel the gratification of shopping, sense fun, and experience enjoyment (Saprikis, Avlogiaris, \& Katarachia, 2021). Moreover, trust provides a pleasant and comfortable online environment to enhance the enjoyment in SNS (Sukhu, Zhang, \& Bilgihan, 2015). Therefore, there can be proposed that the higher trust in the vendor, the more chances the customers will perceive enjoyment.

H8: Trust has a significant positive effect on enjoyment.

In the S-Commerce context, developing trust among the customers is essential to urge and induce them to purchase for achieving higher sales (Kim \& Park, 2013). Thus, trust can be considered as a major prerequisite for S-Commerce success. The empirical study of Liu et al. (2019) has affirmed that trust is a major predictor of customers' decisions in shopping through S-Commerce. Therefore, the following hypothesis is formulated:

H9: Trust has a significant positive effect on behavioral intention.

Enjoyment, a hedonic factor, is an essential component of online shopping to 
ensure the customers can have fun searching and purchasing products or services (Cheema et al., 2013). Therefore, the retailers from S-Commerce should focus on this hedonic factor when selling the products or services. Saprikis et al. (2018) argued that the impression of pleasure, joy, and delight has an effect on customers' behavior that motivates them to shop online. Hence, the following hypothesis has been developed:

H10: Enjoyment has a significant positive effect on behavioral intention.

Based on the above theoretical background and hypotheses development, the research model in this study (Figure 1) integrates the characteristics of S-Commerce as the technical, social, and belief aspects to examine the behavioral intention to purchase (BI). The technological aspect is represented by EA, social aspect by SI and VI, belief aspect by EJ and TR. Besides, the detail of hypotheses and literature support are described in Table 1.

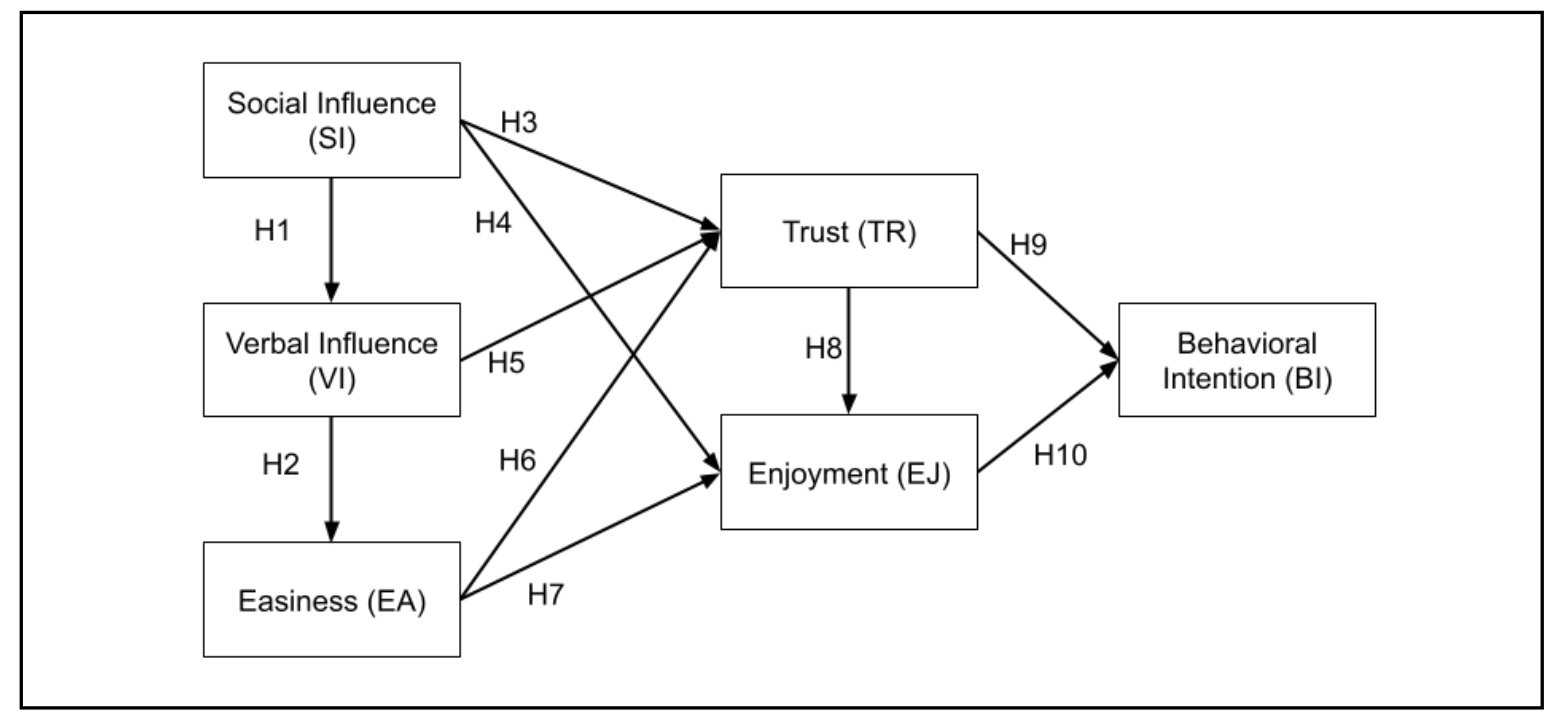

Figure 1: Proposed Research Model

Table 1: Hypotheses with Literature Supports

\begin{tabular}{|c|c|c|c|}
\hline Hypotheses & Relationship & Effect & Literature Support \\
\hline H1 & $\mathrm{SI} \rightarrow \mathrm{VI}$ & $(+)$ & Tsai, Kuo, \& Tan (2017) \\
\hline $\mathrm{H} 2$ & $\mathrm{VI} \rightarrow \mathrm{EA}$ & $(+)$ & Mehrad and Mohammadi (2017) \\
\hline H3 & $\mathrm{SI} \rightarrow \mathrm{TR}$ & $(+)$ & Lee, Cho, and Bae (2017) \\
\hline $\mathrm{H} 4$ & $\mathrm{SI} \rightarrow \mathrm{EJ}$ & $(+)$ & Park et al. (2019) \\
\hline H5 & $\mathrm{VI} \rightarrow \mathrm{TR}$ & $(+)$ & Kumar et al. (2020) \\
\hline H6 & $\mathrm{EA} \rightarrow \mathrm{TR}$ & $(+)$ & Al-Adwan (2019) \\
\hline $\mathrm{H} 7$ & $\mathrm{EA} \rightarrow \mathrm{EJ}$ & $(+)$ & Ashfaq et al. (2019) \\
\hline $\mathrm{H} 8$ & $\mathrm{TR} \rightarrow \mathrm{EJ}$ & $(+)$ & Sukhu, Zhang, and Bilgihan (2015) \\
\hline H9 & $\mathrm{TR} \rightarrow \mathrm{BI}$ & $(+)$ & Liu et al. (2019) \\
\hline H10 & $\mathrm{EJ} \rightarrow \mathrm{BI}$ & $(+)$ & Saprikis et al. (2018) \\
\hline
\end{tabular}




\section{Method}

This study aims to investigate the perceptions of female SNS users toward purchasing in S-Commerce with a cross-sectional study by developing a self-administered questionnaire (Appendix A). Quantitative research was employed and an online survey was used as a research instrument for this study. The questionnaire was created by using Google Form as a tool for online surveys and distributed to the target population through popular SNS such as Facebook, Instagram and LinkedIn. Partly exploratory factor analysis (EFA), partly confirmatory factor analysis (CFA), and structural equation modeling (SEM) techniques were used in the present study to confirm proposed hypotheses (Table 1) and to answer research questions.

The demographic profiles of the female SNS users were collected in the first section of the questionnaire. The questions for demographic profiles consisted of a gender question to identify female users, education level, occupation, and a filter question to ask whether the respondent has prior experience in purchasing products or services from SNS or not. The second section of the questionnaire included 15 indicators (Table 2) used to measure the 6 constructs from the proposed research model (Figure 1). All the indicators used a 5-point Likert scale ranging from 1 (Strongly Disagree) to 5 (Strongly Agree) to measure respondents' attitude. Kline (2011) suggested that minimum 200 cases are required for SEM estimation, therefore, at least 200 data sets are required for the present study.

Table 2: The List of Indicators of Constructs

\begin{tabular}{|c|c|c|}
\hline Factors & Indicators & References \\
\hline Easiness & EA1, EA2 & Sukhu, Zhang, and Bilgihan (2015) \\
\hline Social Influence & SI1, SI2 & Hung, Yu, and Chiu (2018) \\
\hline Verbal Influence & VI1, VI2 & $\begin{array}{l}\text { Barreda, Bilgihan, and Kageyama } \\
\text { (2015) }\end{array}$ \\
\hline Enjoyment & EJ1, EJ2, EJ3 & Cho and Son (2019) \\
\hline $\begin{array}{l}\text { Trust } \\
\text { Behavioral Intention }\end{array}$ & $\begin{array}{l}\text { TR1, TR2, TR3 } \\
\text { BI1, BI2, BI3 }\end{array}$ & Athapaththu and Kulathunga (2018) \\
\hline
\end{tabular}

\section{Results}

\section{Demographic Profiles of Respondents}

Data were collected from female SNS users in Myanmar and 280 female users participated in the present study. 22 respondents (7.9\% of total respondents) were removed for further data analysis because they answered that they do not have prior experience in purchasing products or services through SNS. The result indicates that only 258 respondents are S-Commerce users. 11 cases (4.3\% of S-Commerce users) were eliminated from the data set because each contained at least one outlier value in at least 
one of the indicators; therefore, the valid sample size down to 247. From Table 3 it is seen that the majority of respondents $(45.8 \%)$ are between 26 years and 40 years (generation $\mathrm{Y}$ ), $44.9 \%$ are between 15 years and 25 years (generation $\mathrm{Z}$ ), and only $9.3 \%$ are older than 40 years (generation $\mathrm{X}$ ). Education level of most of the respondents $(60.7 \%)$ are bachelor degree, $25.9 \%$ are master degree, and $1.2 \%$ are pursuing Ph.D. $8.5 \%$ of respondents are holding diplomas and only 3.6\% are high school level. The largest proportion of respondents $(44.5 \%)$ are employees with approximately equal proportions from civil servants and students $(21.9 \%$ and $20.2 \%)$, and $13.4 \%$ of respondents are self-employed.

Table 3: Respondents' Profile

\begin{tabular}{llll}
\hline Demographic & & Frequency $(\mathbf{N}=\mathbf{2 4 7})$ & Percentage(\%) \\
\hline Age & 15-17 years & 2 & 0.8 \\
& 18-20 years & 24 & 9.7 \\
& 21-25 years & 85 & 34.4 \\
& 26-30 years & 46 & 18.6 \\
& 31-35 years & 33 & 13.4 \\
& 36-40 years & 34 & 13.8 \\
Education Level & 23 & 9.3 \\
& >-41 years & 9 & 3.6 \\
& High School & 21 & 8.5 \\
& Diploma & 150 & 60.7 \\
& Bachelor Degree & 64 & 25.9 \\
& Master Degree & 3 & 1.2 \\
Occupation & Ph.D. & 54 & 21.9 \\
& Civil Servant & 110 & 44.5 \\
& Employee & 33 & 13.4 \\
& Self-Employed & 50 & 20.2 \\
\hline
\end{tabular}

\section{Cross-loadings Factor Analysis}

According to the recommendation of Hair et al. (2010), the collected data should be estimated by using Principle Components Analysis (PCA) with varimax rotation to ensure the validity of indicators. The result of cross-loading factor analysis is shown in Table 4 and all the observed indicators have a loading coefficient higher than 0.5 , ranged from .607 to .902 . The cross-loading factor analysis confirmed six constructs affiliated with 15 items and all the proposed indicators are considered to be suitable for further CFA analysis. 
Table 4: Cross-loadings Factor Analysis Result

\begin{tabular}{llllllll}
\hline Factors & Indicators & TR & EA & BI & EJ & VI & SI \\
\hline Trust & TR3 & .807 & .095 & .141 & .112 & .202 & .111 \\
& TR2 & .803 & .136 & .215 & .160 & .124 & .102 \\
Easiness & TR1 & .757 & .060 & .228 & .196 & .191 & .182 \\
Behavioral Intention & EA1 & .048 & .853 & .074 & .246 & .119 & .065 \\
& EA2 & .157 & .840 & .141 & .141 & .102 & .055 \\
Enjoyment & BI & .167 & -.021 & .824 & .245 & .114 & .180 \\
& BI2 & .327 & .352 & .673 & .178 & .178 & .105 \\
Verbal Influence & BI3 & .409 & .291 & .639 & .147 & .162 & .217 \\
& EJ1 & .241 & .090 & .161 & .810 & .137 & .119 \\
Social Influence & EJ2 & .133 & .428 & .171 & .690 & .212 & .137 \\
& EJ3 & .158 & .396 & .306 & .607 & .153 & .025 \\
& VI2 & .180 & .253 & .193 & .145 & .822 & -.001 \\
& SI1 & .279 & .038 & .092 & .195 & .818 & .137 \\
\hline
\end{tabular}

\section{Factor Correlation Analysis}

According to the factor correlation analysis result (Table 5), all of the factors are correlated at 0.01 level. Furthermore, a correlation coefficient of less than .30 is considered a small or weak association, the range between .30 and .49 represents moderate correlation, and the value of .50 or greater is a large or strong correlation (Cohen et al., 2003). Enjoyment (.611) and trust (.630) have large correlation coefficients with behavioral intention. Between enjoyment and easiness (.574) and between trust and verbal influence (.513) also have a strong correlation. The rest of the factor correlation coefficients are moderate except correlation coefficients of social influence with easiness (.207) and verbal influence (.251) are weak. The highlighted cells in Table 6 represent the 10 hypotheses in the proposed research model.

Table 5: Factors Correlation Analysis Result

\begin{tabular}{lllllll}
\hline Factors & EA & SI & VI & EJ & TR & BI \\
\hline Easiness & 1 & & & & & \\
Social Influence & $.207^{* *}$ & 1 & & & & \\
Verbal Influence & $.359^{* *}$ & $.251^{* *}$ & 1 & & & \\
Enjoyment & $.574^{* *}$ & $.342^{* *}$ & $.496^{* *}$ & 1 & & \\
Trust & $.306^{* *}$ & $.413^{* *}$ & $.513^{* *}$ & $.497^{* *}$ & 1 & \\
Behavioral Intention & $.434^{* *}$ & $.478^{* *}$ & $.470^{* *}$ & $.611^{* *}$ & $.630^{* *}$ & 1 \\
\hline
\end{tabular}

Note: ${ }^{* *}$. Correlation is significant at the 0.01 level (2-tailed). 


\section{Convergent Validity and Reliability Analysis}

According to the suggestion of Hair et al. (2010), convergent validity is satisfied if the standardized regression weight of indicators and average variance extracted (AVE) of constructs are greater than .50. As presented in Table 7, the standardized regression weight of indicators ranged from .769 to .922 , and AVE of the constructs ranged from .58 to .66. The analysis results (Table 6) indicate that all factors in the proposed research model achieved acceptable value of Cronbach's Alpha exceeding .70 (Fornell \& Larcker, 1981): enjoyment (.79), trust (.83), easiness (.80), verbal influence (.76), behavioral intention (.82) and social influence (.72). Likewise, composite reliability (CR) of the factors ranged from .75 to .83 . Thus, the findings suggest that convergent validity and reliability is satisfied and suitable for further SEM analysis (Table 6).

Table 6: Convergent Validity and Reliability Analysis Result

\begin{tabular}{lcccc}
\hline Indicators & Std. Regression Weight & AVE & CR & Cronbach's Alpha \\
\hline EJ3 & 0.769 & & & \\
EJ2 & 0.839 & 0.58 & 0.80 & 0.79 \\
EJ1 & 0.658 & & & \\
TR1 & 0.818 & & 0.83 & 0.83 \\
TR2 & 0.795 & 0.62 & & \\
TR3 & 0.752 & & 0.80 & 0.80 \\
EA1 & 0.840 & 0.66 & & \\
EA2 & 0.790 & & 0.76 & 0.76 \\
VI1 & 0.750 & 0.61 & & 0.82 \\
VI2 & 0.815 & & 0.83 & \\
BI2 & 0.822 & & & \\
BI3 & 0.850 & 0.62 & & \\
BI1 & 0.673 & & 0.75 & \\
SI1 & 0.609 & 0.61 & & \\
SI2 & 0.922 & & & \\
\hline
\end{tabular}

\section{Discriminant Validity Analysis}

Fornell and Larcker (1981) suggested that discriminant validity can be verified when the square root of AVE for a factor is greater than its correlations with all other factors. The bolded texts in Table 7 indicate that the square root of AVEs and the results demontrate that all of the correlations of respective factors are lower than the square root of AVE of the respective factors. Therefore, the result is confirmed the discriminant validity. 
Table 7: Discriminant Validity Analysis Result

\begin{tabular}{lllllll}
\hline Factors & EJ & TR & EA & VI & BI & SI \\
\hline Enjoyment (EJ) & $\mathbf{0 . 7 6 2}$ & & & & & \\
Trust (TR) & 0.582 & $\mathbf{0 . 7 8 7}$ & & & & \\
Easiness (EA) & 0.733 & 0.368 & $\mathbf{0 . 8 1 2}$ & & & \\
Verbal Influence (VI) & 0.628 & 0.633 & 0.475 & $\mathbf{0 . 7 8 1}$ & & \\
Behavioral Intention (BI) & 0.730 & 0.768 & 0.554 & 0.600 & $\mathbf{0 . 7 8 7}$ & \\
Social Influence (SI) & 0.414 & 0.520 & 0.251 & 0.271 & 0.584 & $\mathbf{0 . 7 8 1}$ \\
\hline
\end{tabular}

\section{Model Fit Indices Results}

Good-fitting models require the value of $x^{2} / d f$ is less than 3. Further, the values of Goodness-of-Fit Index (GFI), Adjusted Goodness of Fit Index (AGFI), Normed Fit Index (NFI) and Comparative Fit Index (CFI) greater than 0.90 indicate a very good fit of the model (Kline, 2011). Moreover, the value of Root Mean Square Error of Approximation (RMSEA) lower than 0.05 is considered an indication of a good fit (Kline, 2011). In this study, all the value of goodness of fit indices of both measurement model and research model are exceeded than acceptable cutoffs (Table 8).

Table 8: Goodness of Fit Indices Analysis Results

\begin{tabular}{lcccccc}
\hline & $\mathrm{x}^{2} / \mathrm{df}$ & GFI & AGFI & NIF & CFI & RMSEA \\
\hline Acceptable Value & $<3$ & $>.90$ & $>.90$ & $>.90$ & $>.90$ & $<.050$ \\
Measurement Model & 1.196 & .953 & .925 & .950 & .991 & .028 \\
Research Model & 1.374 & .945 & .917 & .939 & .982 & .039 \\
\hline
\end{tabular}

\section{Hypotheses Testing Results}

The hypotheses were investigated as proposed in Table 1 and the results are shown in Table 9. Social influence exerted a significant positive effect on verbal influence $(\beta=0.339, p<0.001)$ and trust $(\beta=0.491, p<0.001)$. Thus, $\mathrm{H} 1$ and $\mathrm{H} 3$ were validated. Verbal influence positively affected easiness $(\beta=0.573, \mathrm{p}<0.001)$ and trust $(\beta=0.590, \mathrm{p}<0.001)$, which means that $\mathrm{H} 2$ and $\mathrm{H} 5$ were supported. Furthermore, enjoyment is positively influenced by easiness $(\beta=0.573, p<0.001)$ and trust $(\beta=0.285, p<0.001)$. Hence, H7 and H8 were validated as well. In addition, trust $(\beta=0.592, p<0.001)$ and enjoyment $(\beta=0.521$, $\mathrm{p}<0.001)$ with regard to $\mathrm{S}$-Commerce, all evidenced a positive effect with intention to purchase. Therefore, H9 and H10 were supported. The analysis results, however, showed that $\mathrm{H} 4$ and $\mathrm{H} 6$ were not accepted. All the significant and insignificant effects are also presented in Figure 2. 
Table 9: Hypotheses Analysis Results

\begin{tabular}{lllll}
\hline Hypothesis & Relationship & Path Coefficient & Effect Magnitude & Result \\
\hline H1 & SI $\rightarrow$ VI & $.339^{* * *}(.297)$ & Medium & Supported \\
H2 & VI $\rightarrow$ EA & $.573^{* * *}(.512)$ & High & Supported \\
H3 & SI $\rightarrow$ TR & $.491^{* * *}(.391)$ & Medium & Supported \\
H4 & SI $\rightarrow$ EJ & .165 NS $(.139)$ & Medium & Not Supported \\
H5 & VI $\rightarrow$ TR & $.590^{* * *}(.537)$ & High & Supported \\
H6 & EA $\rightarrow$ TR & .005 NS $(.005)$ & Small & Not Supported \\
H7 & EA $\rightarrow$ EJ & $.573^{* * *}(.619)$ & High & Supported \\
H8 & TR $\rightarrow$ EJ & $.285^{* * *}(.302)$ & Medium & Supported \\
H9 & TR $\rightarrow$ BI & $.592^{* * *}(.527)$ & High & Supported \\
H10 & EJ $\rightarrow$ BI & $.521^{* * *}(.437)$ & Medium & Supported \\
\hline
\end{tabular}

Note: ${ }^{* * *}$ means $\mathrm{p}<0.001$, NS means No Significant

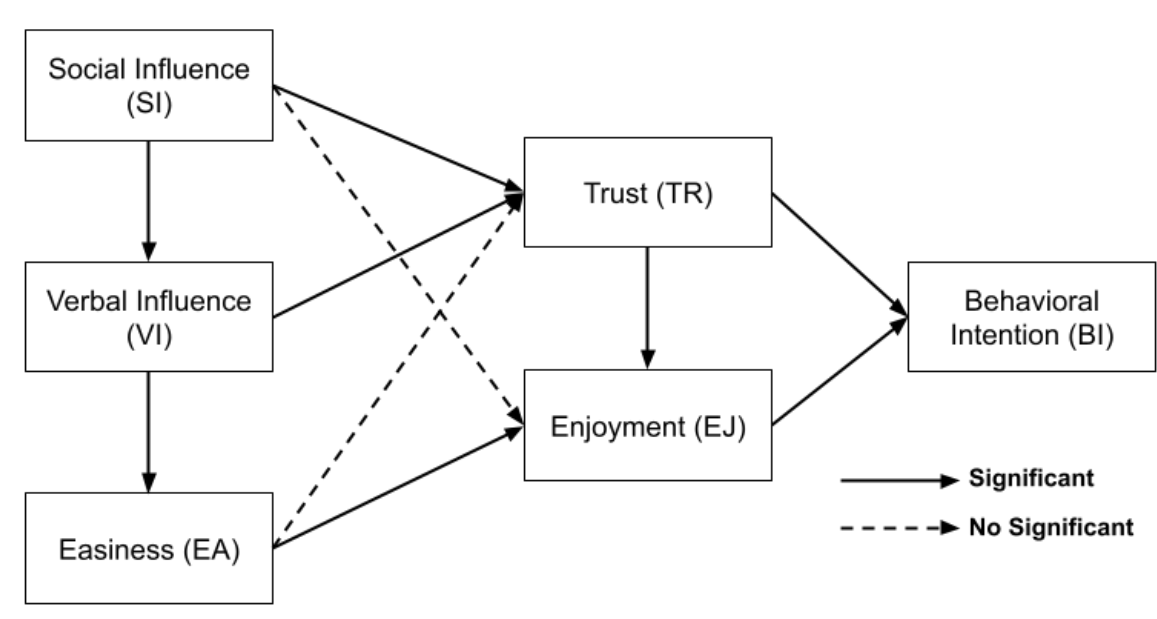

Figure 2: Research Model with Effects

\section{Direct and Indirect Effects in Research Model}

An analysis of both direct and indirect effects in the research model is shown in Table 10 following the guidance of Cohen et al. (2003), and shaded cells indicate the indirect effects in the research model. Social influence is the only independent factor that has a higher direct effect on trust than verbal influence. The research model included four intervening constructs: verbal influence, easiness, trust, and enjoyment. Trust has a stronger direct effect on behavioral intention than enjoyment. Moreover, verbal influence has a high direct effect on both easiness and trust. Also, enjoyment is influenced by easiness with high effect and trust with medium effect. There are eight indirect effects according to the analysis results. All of them have a medium magnitude and significant level at 0.001 . 
Additionally, squared multiple correlations $\left(\mathrm{R}^{2}\right)$ for the endogenous factors (TR, EJ, EA, VI, BI) in the research model are reported in Table 11. For behavioral intention $\left(\mathrm{R}^{2}=74 \%\right)$, the highest amount of variance is explained by the direct effects of trust and enjoyment. More than half of the variance $\left(\mathrm{R}^{2}=57 \%\right)$ in trust is explained by the direct effects of social influence and verbal influence. For enjoyment $\left(R^{2}=69 \%\right)$, the variance is explained by the direct effects of easiness and trust. The result indicates that easiness with $\left(\mathrm{R}^{2}=26 \%\right)$ is the lower accounted for by its predictors (VI) than other variables. Further, verbal influence with $\left(\mathrm{R}^{2}=9 \%\right)$ is the lowest variance among the other endogenous constructs. 
Phyo Min Tun: Female Users' Behavioral Intention to Purchase in Social Commerce through Social Networking Sites

Table 10: Direct and Indirect Effects in Research Model

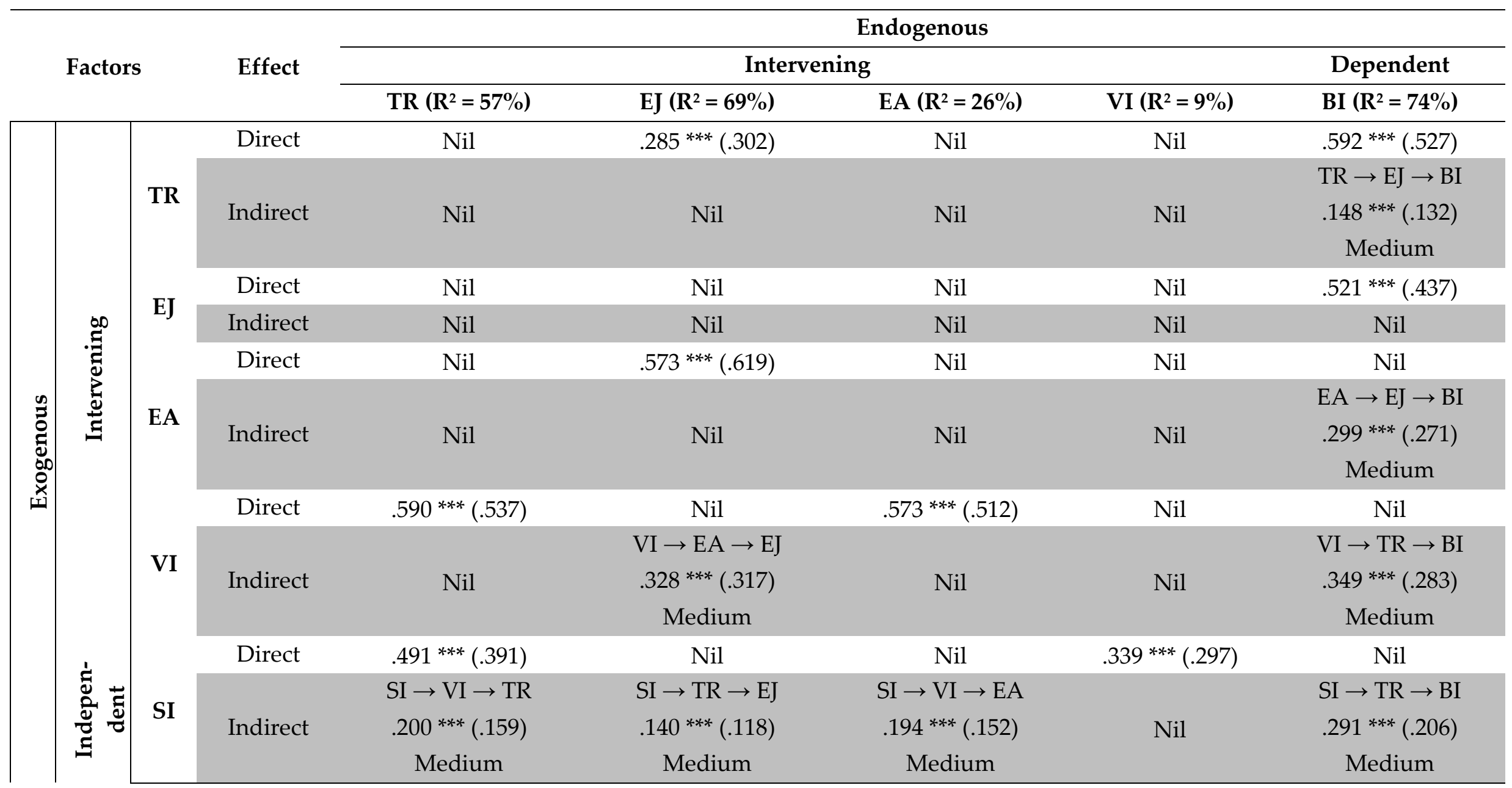




\section{Discussion}

\section{Theoretical Implications}

The results of this study contribute several theoretical implications to the research on behavioral intention to purchase in the S-Commerce context. First, this study indicates that social aspects, such as social influence (H3) and verbal influence (H5), have a significant effect on trust. This means that social activities such as verbal communication, recommendations, and suggestions from friends, family members, and colleagues all exert a strong influence on trust in sellers from S-Commerce. Also, the result of $\mathrm{H} 1$ is consistent with the previous study of Tsai, Kuo, \& Tan (2017). The more customers will be influenced by their friends, family members, and colleagues, the more positive suggestions and recommendations will be created. This study does not confirm the direct effect of social influence on enjoyment (H4) of shopping in S-Commerce. The finding is different from the previous study of Park et al. (2019).

Second, the finding shows that easiness has no significant effect on trust (H6) while there is a high effect on enjoyment (H7). Easiness of using S-Commerce seems to be a crucial issue to improve customers' enjoyment. Ashfaq et al. (2019) also reported a similar result in their study. This study affirmed that easiness is not a prerequisite of trust and it is an unexpected result in S-Commerce. It is possible that the respondents of this study perceived no difficulty in purchasing through SNS and therefore this factor does not contribute to improving trust levels. Likewise, Zhang, et al. (2019) concluded a similar result in their study. Moreover, verbal influence $(\mathrm{H} 2)$ is identified as a significant antecedent of easiness. When the customers are influenced by verbal communication, they are more likely to be perceived the easiness of using S-Commerce. This result is consistent with the prior study of Mehrad and Mohammadi (2017).

Third, the results indicate that trust (H9) and enjoyment (H10) have significant effects on behavioral intention to purchase in S-Commerce. This finding is consistent with previous studies (Liu et al., 2019; Saprikis et al., 2018). Trust is the factor that has a higher effect on behavioral intention to purchase in S-Commerce than enjoyment. Another hypothesis result (H8) reveals that female customers will enjoy shopping more when they think vendors from S-Commerce are reliable. This finding suggests that vendors should emphasize trust-building to improve enjoyment and Sukhu, Zhang, and Bilgihan (2015) also advised a similar approach.

In summary, social influence will not help to enhance the enjoyment of shopping in S-Commerce. However, female customers tend to trust S-Commerce depending on their social circle, and they will enjoy purchasing products or services in S-Commerce only when they have more confidence in S-Commerce (SI $\rightarrow \mathrm{TR} \rightarrow \mathrm{EJ}, \mathrm{SI} \rightarrow \mathrm{TR} \rightarrow \mathrm{BI}$ ). They also rely on verbal communication to trust vendors in S-Commerce for shopping $(\mathrm{VI} \rightarrow \mathrm{TR} \rightarrow \mathrm{BI})$. Further, social influence generates positive verbal communications 
which lead to trust sellers in S-Commerce $(\mathrm{SI} \rightarrow \mathrm{VI} \rightarrow \mathrm{TR})$ and assist them to learn easily how to purchase in S-Commerce (SI $\rightarrow \mathrm{VI} \rightarrow \mathrm{EA}$ ). The finding indicates that the cause of perceiving the easiness of using S-Commerce is verbal communication and eventually female customers will think shopping in S-Commerce is fun (VI $\rightarrow$ EA $\rightarrow$ $\mathrm{EJ})$. The results also imply that higher trust (TR $\rightarrow \mathrm{EJ} \rightarrow \mathrm{BI}$ ) and easiness of using SCommerce $(\mathrm{EA} \rightarrow \mathrm{EJ} \rightarrow \mathrm{BI}$ ) will increase the enjoyment of shopping in S-Commerce. But there can be asserted that easiness does not improve female customers' confidence in S-Commerce according to the finding.

\section{Managerial Implications}

In this study, social influence is an antecedent of both verbal influence and trust. Verbal influence is more critical than social influence to build trust in sellers from S-Commerce. Vendors from S-Commerce should duly create promotion events and referral marketing plans that will ensure the customers encourage their family members, friends, and colleagues to buy products or services and spread positive opinions regarding their shopping experience to their social peers. In this case, vendors can expand not only a large market proportion through a wide social circle with social interactions between existing customers and potential new customers to attract them to purchase but also increase the confidence of customers.

Positive opinions and recommendations will ensure the customers to be perceived the easiness of purchasing in S-Commerce. Vendors should note that customers will accept that purchasing in S-Commerce is easy when their social peers talk more positive things about S-Commerce. Also, there can be asserted that enjoying shopping in S-Commerce is depending on the easiness of use and trust in sellers. Therefore, sellers from S-Commerce should focus on building trust with their customers and facilitating their customers to purchase easily. If female customers are able to buy or search for the desired products or services through SNS platforms more easily, they will enjoy more shopping in S-Commerce. In addition, the abundant suggestions and advices from popular social influencers regarding online retailers and particular products will also be helpful to improve trustworthiness.

Enjoyment in shopping and trusting in retailers are essential motivations for the customers to purchase products and services from S-Commerce. Vendors should ensure the customers feel that shopping in S-Commerce is fun and exciting by creating and developing entertainment programs using available features of SNS such as broadcasting live videos, uploading entertainment videos, and formulating social interactive marketing campaigns. Furthermore, vendors should beware that the information they provide to customers must be reliable and accurate. Vendors, therefore, should check and validate the accuracy of the information before they share it with their customers. Otherwise, the customers will think the seller is not sincere and 
honest, then trust in the seller will be undermined.

\section{Conclusion}

The major purpose of the present study is to identify which factors affected intention of female SNS users to purchase products or services from S-Commerce in Myanmar. In this research, the integration of the technical, social, and belief dimensions in SCommerce context is one of the novelties. The results of this study can be concluded that trust and enjoyment are indispensable factors for making shopping decisions in SCommerce, thereby answering RQ1. Higher trust will achieve greater enjoyment in shopping. Moreover, social aspects (social influence and verbal influence) have significant effects on vendor trust and only verbal influence is significant for the female customers to be perceived the easiness then lead to enjoyment in S-Commerce, therefore answering RQ2. In addition, the theoretical and managerial implications of this study will be beneficial for vendors who plan to sell products and services using SNS platforms. Moreover, the insights and knowledge of this study may encourage existing or potential female SNS users to participate in S-Commerce.

This research study has some inescapable limitations. Firstly, since Facebook dominates as the major role among the SNS users in Myanmar, the data for this study was collected only from one SNS platform, Facebook. The opinions of SNS users from other popular SNS platforms such as Instagram and LinkedIn were excluded. Secondly, this research reflects only the perceptions of female SNS users only and male SNS users are not considered. Thirdly, the respondents had prior experience in purchasing products or services through SNS platforms and the results, therefore, may not represent other potential inexperienced S-Commerce customers. Finally, this research study was conducted only in Myanmar which means the employed research model may not be suitable for other countries because there is different online shopping behavior in different countries and cultures.

For future research, the findings of this study can be reasonably extended by supplementing more constructs to broaden the scope of study in S-Commerce context. There are a variety of activities in the SNS platform, and future studies can focus on other activities such as gaming, communicating, sharing information, and business advertising rather than shopping in order to more apprehend S-Commerce. Furthermore, future researchers also can divide the three dimensions of trust namely, trust in vendors, trust in service, and trust in S-Commerce technology and examine if one dimension is more vital than the others in S-Commerce context.

\section{Author's Declaration}

The author made substantial contributions to the conception and design of the study. The author took responsibility for data analysis, interpretation and discussion of 
results. The author read and approved the final manuscript.

\section{ORCID}

Phyo Min Tun (D) https://orcid.org/0000-0003-2092-6671

\section{References}

Adam, A. B., Jizat, J. E., \& Nor, M. A. (2016). Internal factors within entrepreneurs that influence the acceptance and use of Social commerce among SMEs in Malaysia. Development Research of Management, 11(1), 35-45.

Ahmad, S. A.-A. (2019). Revealing the Influential Factors Driving Social Commerce Adoption. Interdisciplinary Journal of Information, Knowledge, and Management, 14, 295-324.

Ajzen, I. (1991). The theory of planned behavior. Organizational behavior and human decision processes, 50(2), 179-211.

Al-Adwan, A. S. (2019). Revealing the influential factors driving social commerce adoption. Interdisciplinary Journal of Information, Knowledge, and Management, 14, 295-324.

Almaimouni, A., Houghton, L., \& Sandhu, K. (2014). Impact of Social Influence on Entrepreneurs to Use e-Commerce in Saudi Arabia. International Journal of Computer Science and Information Technologies, 5(6), 7761-7772.

Ashfaq, M., Yun, J., Waheed, A., Khan, M. S., \& Farrukh, M. (2019). Customers' Expectation, Satisfaction, and Repurchase Intention of Used Products Online: Empirical Evidence From China. SAGE Open, 9(2), 1-14.

Athapaththu, J. C., \& Kulathunga, D. (2018). Factors Affecting Online Purchase Intention: Effects of Technology and Social Commerce. International Business Research, 11(10), 111-128.

Baethge, C., Klier, J., \& Klier, M. (2016). Social commerce-state-of-the-art and future research directions. Electronic Markets, 26(3), 269-290.

Barreda, A. A., Bilgihan, A., \& Kageyama, Y. (2015). The Role of Trust in Creating Positive Word of Mouth and Behavioral Intentions: The Case of Online Social Networks. Journal of Relationship Marketing, 14(1), 16-36.

Biucky, S. T., Abdolvand, N., \& Harandi, S. R. (2017). The effects of perceived risk on social commerce adoption based on the tam model. International Journal of Electronic Commerce Studies, 8(2), 173-196.

Bone, P. (1995). Word-of-mouth effects on short-term and long-term product judgements. Journal of Business Research, 32(3), 213-223.

Bostrom, R. P., \& Heinen, J. S. (1977). MIS Problems and Failures: A Socio-Technical Perspective, Part II: The Application of Socio-Technical Theory. MIS Quarterly, 1(4), 11-28.

Cheema, U., Rizwan, M., Jalal, R., Durrani, F., \& Sohail, N. (2013). The Trend of Online Shopping in 21st Century: Impact of Enjoyment in Tam Model. Asian Journal of Empirical Research, 3(2), 131-141.

Chesney, T. (2006). An Acceptance Model for Useful and Fun Information Systems. Human Technology, 2(2), 225-235. 
Cho, E., \& Son, J. (2019). The effect of social connectedness on consumer adoption of social commerce in apparel shopping. Fashion and Textiles, 6(14), 1-17.

Chu, S.-C., \& Choi, S. M. (2011). Electronic Word-of-Mouth in Social Networking Sites: A Cross-Cultural Study of the United States and China. Journal of Global Marketing, 24(3), 263-281.

Cohen, J., Cohen, P., West, S. G., \& Aiken, L. S. (2003). Applied multiple regression/correlation analysis for the behavioral sciences (3rd ed.). New York: Lawrence Erlbaum Associates.

Culnan, M. J., McHugh, P. B., \& Zubillaga, J. I. (2010). How large U.S. companies can use Twitter and other social media to gain business value. MIS Quarterly Executive, 9(4), 243-260.

Davis, F. D. (1989). Perceived Usefulness, Perceived Ease of Use, and User Acceptance of Information Technology. MIS Quarterly, 13(3), 319-340.

Davis, F. D., Bagozzi, R. P., \& Warshaw, P. R. (1992). Extrinsic and Intrinsic Motivation to Use Computers in the Workplace. Journal of Applied Social Psychology, 22(14), 1111-1132.

Dickinger, A., Arami, M., \& Meyer, D. (2008). The role of perceived enjoyment and social norm in the adoption of technology with network externalities. European Journal of Information Systems, 17(1), 4-11.

Flanagin, A. J., Metzger, M. J., Pure, R., Markov, A., \& Hartsell, E. (2014). Mitigating risk in ecommerce transactions: perceptions of information credibility and the role of user-generated ratings in product quality and purchase intention. Electronic Commerce Research, 14, 1-23.

Fornell, C., \& Larcker, D. F. (1981). Evaluating Structural Equation Models with Unobservable Variables and Measurement Error. Journal of Marketing Research, 18(1), 39-50.

Gefen, D., Karahanna, E., \& Straub, D. W. (2003). Trust and TAM in Online Shopping: An Integrated Model. MIS Quarterly, 27(1), 51-90.

Goh, T.-T., \& Sun, S. (2014). Exploring gender differences in Islamic mobile banking acceptance. Electronic Commerce Research, 14(4), 435-458.

Goyette, I., Ricard, L., Bergeron, J., \& Marticotte, F. (2010). e-WOM scale: word-ofmouth measurement scale for e-services context. Canadian Journal of Administrative Science, 27(1), 5-23.

Hair, J., Black, W., Babin, B., \& Anderson, R. (2010). Multivariate Data Analysis (7th ed.). Upper Saddle River, NJ: Prentice-Hall.

Hajli, N., \& Sims, J. (2015). Social commerce: The transfer of power from sellers to buyers. Technological Forecasting and Social Change, 94, 350-358.

Hajli, N., Wang, Y., Tajvidi, M., \& Hajli, S. (2017). People, technologies, and organisations interactions in a social commerce era. IEEE Transactions on Engineering Management, 64(4), 594-604.

Han, B., \& Windsor, J. (2011). User's willingness to pay on social network sites. The Journal of Computer Information Systems, 51(4), 31-40. 
Huang, Z., \& Benyoucef, M. (2013). From E-Commerce to Social Commerce: A Close Look at Design Features. Electronic Commerce Research and Applications, 12(4), 246259.

Hung, S.-Y., Yu, A. P.-I., \& Chiu, Y.-C. (2018). Investigating the factors influencing small online vendors' intention to continue engaging in social commerce. Journal of Organizational Computing and Electronic Commerce, 28(1), 9-30.

Kemp, S. (2020, February 18). DIGITAL 2020: MYANMAR. Retrieved June 10, 2020, from DATAREPORTAL: https://datareportal.com/reports/digital-2020-myanmar

Kim, S., \& Park, H. (2013). Effects of various characteristics of social commerce (scommerce) on consumers' trust and trust performance. International Journal of Information Management, 33(2), 318-332.

Kline, R. B. (2011). Principles and Practice of Structural Equation Modeling (3rd ed.). New York: The Guilford Press.

Koenig-Lewis, N., Marquet, M., Palmer, A., \& Zhao, A. L. (2015). Enjoyment and social influence: predicting mobile payment adoption. The Service Industries Journal, 35(10), 537-554.

Kumar, S., Stacia, J. C., Suriana, Y., Sari, H. D., \& Meydia. (2020). Website Quality and Purchase Intention: The Role of Participation, E-Wom, and Trust. AFEBI Management and Business Review (AMBR), 5(2), 1-14.

Laughlin, J., \& MacDonald, J. (2010). Identifying market mavens online by their social behaviors in community-generated media. Academy of Marketing Studies Journal, 14(1), 55-70.

Lee, C. C., Cho, Y. S., \& Bae, B. B. (2017). Factors Affecting Trust in Social Commerce: A Structural Equation Model. Issues in Information Systems, 18(4), 70-90.

Lee, S.-Y. T., \& Phang, C. W. (2015). Leveraging social media for electronic commerce in Asia. Electronic Commerce Research and Applications, 14(3), 145-149.

Leeraphong, A., \& Papasratorn, B. (2018). Business Models and Transactions in C2C Social Commerce: Practices of Selected Social Commerce Practitioners in Thailand. International Journal of Innovation and Technology Management, 15(6), 128.

Liang, T., \& Turban, E. (2011). Introduction to the special issue social commerce: a research framework for social commerce. International Journal of Electronic Commerce, 16(2), 5-14.

Lin, M.-J. J., \& Huang, C.-H. (2013). The impact of customer participation on NPD performance: The mediating role of inter-organisation relationship. Journal of Business \& Industrial Marketing, 28(1), 3-15.

Lin, X., Li, Y., \& Wang, X. (2016). Social commerce research: Definition, research themes and the trends. International Journal of Information Management, 37(3), 190201.

Lin, X., Zhang, D., \& Li, Y. (2016). Delineating the dimensions of social support on social networking sites and their effects: A comparative model. Computers in Human Behaviour, 58(1), 421-430. 
Liu, Y., Su, X., Du, X., \& Cui, F. (2019). How social support motivates trust and purchase intentions in mobile social commerce. Revista Brasileira de Gestao de Negocios, 21(5), 839-860.

Lu, B., Fan, W., \& Zhou, M. (2016). Social presence, trust, and social commerce purchase intention: An empirical research. Computers in Human Behaviour, 56(1), 225-237.

McKnight, D. H., Choudhury, V., \& Kacmar, C. (2002). The impact of initial consumer trust on intentions to transact with a web site: A trust building model. The Journal of Strategic Information Systems, 11(3), 297-323.

Mehrad, D., \& Mohammadi, S. (2017). Word of Mouth impact on the adoption of mobile banking in Iran. Telematics and Informatics, 34(7), 1351-1363.

Miranda, F. J., Rubio, S., Chamorro, A., \& Loureiro, S. M. (2014). Using Social Networks Sites in the Purchasing Decision Process. International Journal of EBusiness Research, 10(3), 18-35.

Mutz, D. (2005). Social trust and e-commerce: experimental evidence for the effects of social trust on individuals' economic behavior. Public Opinion Quarterly, 69(3), 393-416.

Newton, D. A., \& Burgoon, J. K. (2006). The Use and Consequences of Verbal Influence Strategies During Interpersonal Disagreements. Human Communication Research, 16(4), 477-518.

Ngai, E. W., Tao, S. S., \& Moon, K. K. (2015). Social media research: Theories, constructs, and conceptual frameworks. International Journal of Information Management, 35(1), 33-44.

Park, J. K., Ahn, J., Thavisay, T., \& Ren, T. (2019). Examining the role of anxiety and social influence in multi-benefits of mobile payment service. Journal of Retailing and Consumer Services, 47, 140-149.

Pavlou, P. A. (2003). Consumer Acceptance of Electronic Commerce: Integrating Trust and Risk with the Technology Acceptance Model. International Journal of Electronic Commerce, 7(3), 101-134.

Pavlou, P. A., \& Ba, S. (2002). Evidence of the Effect of Trust Building Technology in Electronic Markets: Price Premium and Buyer Behavior. MIS Quarterly, 26(3), 243-268.

Ramayah, T., \& Ignatius, J. (2005). Impact of Perceived Usefulness, Perceived Ease of Use and Perceived Enjoyment on Intention to Shop Online. ICFAI Journal of Systems Management, 3(3), 36-51.

Raza, M. A., Ahad, M. A., Shafqat, M. A., Aurangzaib, M., \& Rizwan, M. (2014). The Determinants of Purchase Intention towards Counterfeit Mobile Phones in Pakistan. Journal of Public Administration and Governance, 4(3), 1-19.

Sago, B. (2010). The influence of social media message sources on Millenial Generation consumers. International Journal of Integrated Marketing Communication, 2(2), 7-18.

Sangwan, S., Siguaw, J., \& Guan, C. (2009). A Comparative Study of Motivational Differences for Online Shopping. ACM SIGMIS Database, 40(4), 28-42.

Saprikis, V., Avlogiaris, G., \& Katarachia, A. (2021). Determinants of the Intention to Adopt Mobile Augmented Reality Apps in Shopping Malls among University 
Students. Journal of Theoretical and Applied Electronic Commerce Research, 163(3), 491-512.

Saprikis, V., Markos, A., Zarmpou, T., \& Vlachopoulou, M. (2018). Mobile Shopping Consumers' Behavior: An Exploratory Study and Review. Journal of Theoretical and Applied Electronic Commerce Research, 13(1), 71-90.

Slyke, C. V., Comunale, C. L., \& Belanger, F. (2002). Gender Differences in Perceptions of Web-Based Shopping. Communications of the ACM, 45(8), 82-86.

Stephen, A. T., \& Toubia, O. (2010). Deriving value from social commerce networks. Journal of Marketing Research, 47(2), 215-228.

Sukhu, A., Zhang, T., \& Bilgihan, A. (2015). Factors Influencing Information-Sharing Behaviors in Social Networking Sites. Services Marketing Quarterly, 36(4), 317-334.

Tsai, C.-H., Kuo, C.-C., \& Tan, M. J. (2017). The Cause and Effects of Word of Mouth from Consumer Intention and Behavior Perspectives: A SEM Model Approach. Economic and Social Thought, 4(2), 212-231.

Tun, P. M. (2012). Impact of Social Networking Websites on Business Today. AU-GSB e-Journal, 5(2), 41-45.

Tun, P. M. (2020). Factors Influencing Intention to Reuse Mobile Banking Services for the Private Banking Sector in Myanmar. ASEAN Journal of Management $\mathcal{E}$ Innovation, 7(1), 63-78.

Venkatesh, V., \& Bala, H. (2008). Technology Acceptance Model 3 and a Research Agenda on Interventions. Decision Sciences, 39(2), 273-315.

Venkatesh, V., \& Davis, F. D. (2000). A Theoretical Extension of the Technology Acceptance Model: Four Longitudinal Field Studies. Management Science, 46(2), 186-204.

Wang, Y., \& Yu, C. (2015). Social interaction-based consumer decision-making model in social commerce: The role of word of mouth and observational learning. International Journal of Information Management, 37(3), 179-189.

Zhang, K. Z., \& Benyoucef, M. (2016). Consumer behavior in social commerce: A literature review. Decision Support Systems, 86, 95-108.

Zhang, T., Tao, D., Qu, X., Zhang, X., Lin, R., \& Zhang, W. (2019). The roles of initial trust and perceived risk in public's acceptance of automated vehicles. Transportation Research Part C: Emerging Technologies, 98, 207-220.

Zhou, L., Zhang, P., \& Zimmermann, H. (2013). Social commerce research: an integrated view. Electronic commerce research and applications, 12(2), 61-68. 


\section{Appendix A}

\section{Indicators Statements}

TR1 I believe that the information that I get from sellers in s-commerce is reliable.

TR2 The sellers in s-commerce keep promises and commitments.

TR3 Most of the information from sellers in s-commerce is sincere and honest.

EJ1 Purchasing products and services through s-commerce is entertaining and

fun.

EJ2 Purchasing products and services through s-commerce is interesting.

EJ3 Purchasing products and services through s-commerce is exciting.

EA1 It is easy to learn how to purchase products and services in s-commerce.

EA2 It is easy to become skillful at purchasing products and services in scommerce.

I have only positive things to say about purchasing products and services from s-commerce.

VI2 I mostly tell people positive things about sellers from s-commerce.

SI1 People who influence my decisions think that I should purchase products and services in s-commerce. People who are important to me think that I should purchase products and services in s-commerce.

BI1 I will consider s-commerce first when I want to purchase products or services.

BI2 I intend to use s-commerce frequently to purchase products or services.

BI3 I intend to purchase products or services increasingly from s-commerce. 